\title{
A Critical Review on Ethnobotanical, Phytochemical and Pharmacological Investigations of Martynia annua Linn.
}

\author{
Review Article
}

\author{
Rahul Kumar Gupta ${ }^{1 *}$, Meena Deogade ${ }^{2}$ \\ 1. PhD Scholar, 2. Professor, \\ MGAC \& HRC, Wardha(H), Maharashtra, India
}

\begin{abstract}
Martynia annua Linn (Martyniaceae) is an important herbaceous annual medicinal herb found as a wild plant throughout India. In spite of the fact that the majority of its parts are utilized as a part of folklore and it is known as kakanasika in Ayurved, fruits, seeds, roots and Leaves are the most vital parts which are utilized therapeutically. The present article gives an account of updated complete information on its phytochemical and pharmacological properties. The review shows that large numbers of phytochemical constituents have been isolated from the Martynia annua Linn plant which possesses actions like Antioxidant, Anthelmintic, Analgesic and Antipyretic, Antibacterial, Anti-convulsant, Antinociceptive and, Antifertility, Central Nervous System (CNS) depressant, Wound Healing, Antidiabetic, Gastroprotective, Antifungal, Cytotoxic Activity and various other important medicinal properties. In folk medicine, Decoction of whole plant is used in pneumonia and cold fever. Leaves are eaten in times of scarcity and also given in epilepsy and its juice is gargled for sore throat. The fruits are used for the treatment of asthma; the seeds are also applied locally for itching and eczema. The Roots are boiled with milk and taken as a tonic and roots made into a poultice and applied in snake bite. For the last few decades or so, extensive research work has been done to prove its biological activities and pharmacology of its extracts. The aim of this review article was to summarize the information associated to Pharmacognostical, ethnobotanical, traditional, Phytochemical and pharmacological activity of the Martynia annua Linn plant.
\end{abstract}

Keywords: Martynia annua Linn, Martyniaceae, Kakanasika, Antioxidant, Cytotoxic Activity.

\section{Introduction}

Martynia annua Linn (Family: Martyniaceae)

is a folklore medicinal plant used to heal wounds and treat cancer, rheumatism, epilepsy, inflammation, sore throat, burns, itching, respiratory tract and skin diseases . It is commonly found in dense clumps on roadsides, degraded moist and dry deciduous forest, waste lands and over-grazed pasture. It is a weedy alien species native to tropical and sub-tropical region of Mexico, Central America, Burma, West Pakistan and naturalized throughout India. Its excellent dispersal mechanism has helped it extend throughout the tropical world as a wild plant.(1)

The plant is commonly known as the Cat's claw or Devil's claw because of the 2-hooked form of their seed pods. In Ayurveda, the plant is known as Kakanasika and it is also important ingredient of Chyavanprasha avaleha \& Tryushnadi Ghrita.(2) Materia medica of India gives bunches of data on the folklore practices and conventional aspects of therapeutically important natural products. The evaluation of these drugs is mostly based on Pharmacognostical, Phytochemical and Pharmacological investigation.(3)

*Corresponding Author:

\section{Rahul Gupta}

MGAC\&HRC,

Wardha(H),

Maharashtra, India

Email: drrahulkgupta17@gmail.com

\section{Aim and objective}

The aim of this review is to summarize the information and knowledge about the Martynia annua Linn and updating available research data on the aspects of botany, Pharmacognosy, phytochemistry, ethno pharmacology and Pharmacological studies.

\section{Materials and methods}

Information obtained about Martynia annua Linn from classical textbooks as well as Research papers published on Martynia annua Linn were collected from internet.

\section{Vernacular Name}

Martynia annua Linn is commonly known as "Devil's claw", "Tiger's claw" in English, "Hathajori", "Bichu", 'Ulat-kanta" in Hindi, "Vichchida" in Gujrati, "Vinchu" in Marathi, "Puli Nakham" in Malayalam, "Baghnoki" in Bengali, "Thelkodukkukkay", "Puli-nagam" in Tamil, "Garudamukku", "Telukondicchhettu" in Telugu, "Shernui" in Konkani.(4)

\section{Classical Review \\ Charaka Samhita:}

Acharya Charaka has mentioned Kakanasa as ingredients of Chyavanprashavaleha for Rasayan Karma (5), as ingredients of Tryushnadi Ghrita for Kasa Rog (6), as ingredients of Dhupan Dravya for Apasmara Rog (7) and as ingredients of Baladi yamak sneha for Yoni roga chikitsa (8). 


\section{Sushruta Samhita}

Acharya Sushruta has mentioned Kakanasa as ingredients of Anuvasan Vasti Dravya along with other drugs.(9)

\section{Dhanwantari Nighantu}

This is one of the most authentic texts of Dravyaguna written in 7-10th century A.D. In this text Author has categorised this plant in Karveeradi Varga and Kakanasa has its synonyms as Dhankshnasa, Kaktundphala, surangi, Taskarsnayu and Dhwankshtundaphala. It is said to have Tikta (Bitter) Rasa, Ushna Virya and is used for Purification of wound (External use), constipation and its fruits are used for preparation of oil.(10)

\section{Kaidev Nighantu}

This is one of the most authentic texts of Dravyaguna written in 14 th century A.D. In this text Author has categorised this plant in Aushadhi Varga and Kakanasa has its synonyms as Chorsnayu, Jeevaniya, Kakangi, Kakasya, Kakasyasya, Shirobala and Surangika. It is constituted by Kashaya(Astringent), Tikta (Bitter) Tikta, Katu (Pungent) Rasa, has katu vipaka and is Ushna Virya. It is used in Shotha, Rakta Vikar, Switra, Kushtha, Kaphaj Vikar and it also used for emetic purposes.(11)

\section{Bhavprakash Nighantu}

This is one of the most authentic texts of Dravyaguna written in 16 th century A.D. In this text Author has categorised this plant in Guduchiyadi Varga and According Acharya Chunekar Fruit paste of Martynia annua Linn is used in scorpion Bite by Local use and Oil prepared by Fruits is used in various Skin Disorders by Local application and Leaf paste is used in Apachi by Local application.(12)

\section{Raj Nighantu}

This is one of the most authentic texts of Dravyaguna written in 17 th century A.D. In this text author has categorised this plant in Guduchiyadi Varga. It is constituted by Madhur(Sweet) Rasa, has Sheet Virya. It is used in Pittaj disorders, Greying of Hairs and It is used as Rasayana(Rejuvenation) and Root, Whole plant and Fruit are the useful parts of Martynia annua Linn.(13)

\section{Adarsha Nighantu:}

This is an Ayurvedic text in which the content of Dravyaguna has been discussed at large. In this text author has categorised this plant in Arkadi Varga. The different synonyms and regional names have been told. According to Acharya Vapalal Vaidya Kakanasa is controversial drug and Fruit of Kakanasa Should be resemblance with Beak of crow and due to this Pentatropis microphylla should be considered as original Kakanasa And Martynia annua Linn has Trikantak (3 hooks) in shape and Trikantak is synonym given to Gokshur in ayurvedic literature so according to him due to its shape it should be considered as original Gokshura.(14)
Botanical descriptions of Martynia annua Linn (1518)

Martynia annua Linn is herbaceous, solid, erect, expanded, soggy pubescent, annual plant creating to a height of $0.25-1 \mathrm{~m}$, secured with thick glandular sticky hairs. The Stems are erect and typically woody at base.

Leaves are kidney-shaped, inverse with lamina reniform, $15-23 \mathrm{~cm}$ wide, chordate, sinuate lobed, limp, peak intense, base chordate, margins entire to shallow-sinuate to be toothed, palmately veined, petiole 9- $14 \mathrm{~cm}$ long and sticky-topped glandular hairs exhibit on both the upper and lower leaf sharp edge surfaces.

Flowers are bell shaped, purplish white, with dim purple markings and sick noticing having raceme inflorescence. Pedicels $1-2 \mathrm{~cm}$ long, thickening and recurved in natural product. Calyx is around 15-20 mm long. Corolla is around $55-65 \mathrm{~mm}$ in general, tube around $35-45 \mathrm{~mm}$ long. Corolla is pipe shape campanulate, spotted on the inward surface, the spots yellow, pink or purple. Stamens are two.

Fruits are hard, bi-lobed, and woody with 2 sharp recurved snares

Seeds are brown to black, 2 to each pod.

Morphological characters of Martynia annua Linn as shown in fig. 1.
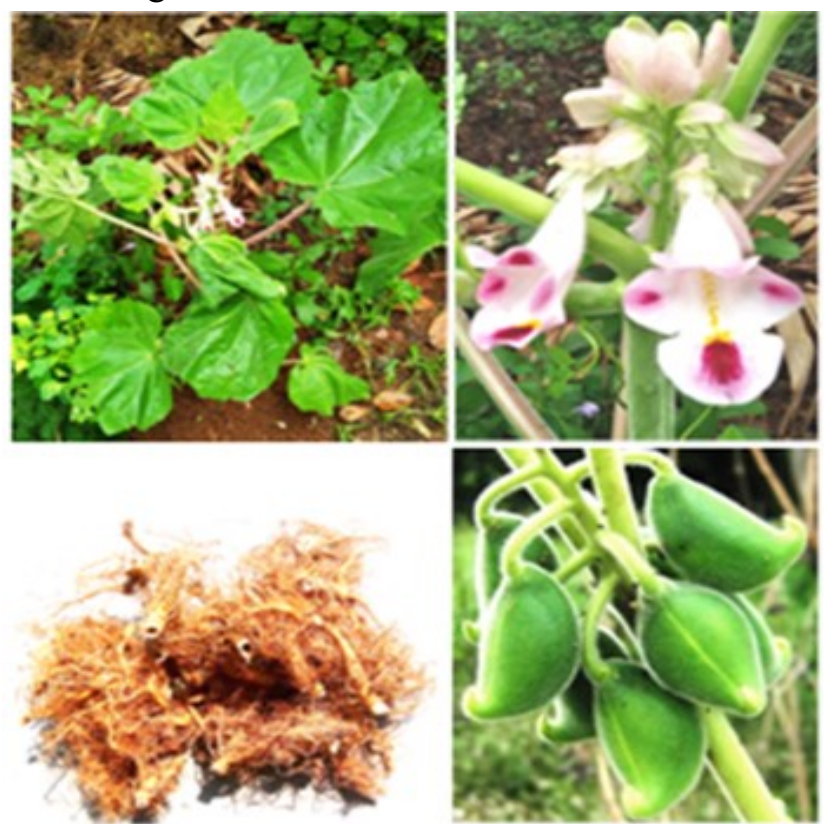

Fig 1: Martynia annua Linn plant

\section{Microscopy of Martynia annua Linn.}

Transverse section of leaf is charactering by presence of multicellular covering trichome on upper and lower epidermis, palisade cell, spongy parenchyma, vascular bundle and collenchyma as below the upper epidermis and above lower epidermis. Transverse section of stem of Martynia annua Linn is charactering by existence of trichome, parenchymatous cortex, endodermis, vascular bundles and centralize pith and transverse section of root of Martynia annua Linn is charactering by existence of epidermis, parenchymatous cortex, endodermis and vascular bundles $(4,19)$. 


\section{Powder Microscopy}

Powder microscopy of plant is characterizing by the presence of spiral vessel, stomata, trichome and breaded epidermis(20)

\section{Physicochemical parameters of Martynia annua Linn.(21)}

Physicochemical constraint includes moisture content, total ash, acid insoluble ash, water soluble ash, water and alcohol soluble extractive. Table 1 provides a summary focusing on the values for physicochemical parameter.

\section{Table 1: Physico-chemical characters of the leaf powder of Martynia annua Linn}

\begin{tabular}{|l|l|l|}
\hline S. No. & Parameter & Values (\%) \\
\hline 1. & Total Ash & $4.1 \%$ \\
\hline 2. & Acid insoluble ash & $0.3 \%$ \\
\hline 3. & Water Soluble Ash & $2.21 \%$ \\
\hline 4. & Moisture Contents & $81.1 \%$ \\
\hline
\end{tabular}

\section{Propagation}

It is propagated by seed propagation method which remains inside the pod and attaches itself by its spines to vehicles, machinery, animals and humans. Flowering and fruiting season of plant is Aug.-Sept.

\section{Properties And Actions of Martynia annua Linn(1)}

Martynia annua Linn is considered as Kaknasika in Ayurved and it has Madhura Rasa, Madhura Vipaka, Sheeta Virya and Pittaghna, rejuvenating properties and important formulations are Chyavanprasha Avaleha and Tryushanadi ghrita and it is used in Palita and therapeutic Dose of drug is 2-5 gm in powder form.
Traditional and Ethnobotanical information of Martynia annua Linn.

Plant is used in Indian traditional medicine and in folklore for curing various diseases and each part of the plant is being used to treat many diseases. Plant is being used in Indian traditional medicines for epilepsy, inflammation and tuberculosis.(2) the leaves of the plant are eaten in times of scarcity and also used as antiepileptic and antiseptic, applied locally to tuberculous glands of the neck, leaves juice used as a gargle for treating sore throat and leaf paste for curing wounds of domestic animals.(22,23) The fruits of Martynia annua Linn used as local sedative and also used as antidote to scorpion stings to venomous bites and stings. The fruit is considered alexiteric and useful in inflammations while ash of fruit mixed with coconut oil applied on burns.(2) Seed oil applied on abscesses and for treating itching and skin affections. The Ayurvedic Pharmacopoeia of India suggested the uses of Martynia annua Linn seed in graying of hair.(20) The fruits of Martynia annua Linn used as local sedative and also used as antidote to scorpion stings to venomous bites and stings. Whole plant is also used by santal tribals for fever, hair loss, scabies, sore and carbuncles on the back. It has been used from ancient time in traditional medicine of India. In folk medicine, the fruits are used for the treatment of asthma; the seeds are applied locally for itching and eczema. The leaves are given in epilepsy and its juice is gargled for sore throat. Decoction of whole plant is given in pneumonia and cold fever. The roots made into a poultice and applied in snake bite.(25) Roots of Martynia annua Linn are boiled in milk and taken as a tonic in folklore.(26) In Tribal Pockets of Satpura Plateau in Madhya Pradesh, Root paste of Martynia annua Linn is used in folk medicine to treat Cancer and rheumatism.(27) A detailed view of the ethnomedicinal uses of different parts of the plant is given in Table 2.

Table 2: - Ethanobotanical information on Martynia annua Linn.

\begin{tabular}{|l|l|l|l|l|}
\hline S. No. & Plant part & Preparation & Traditional uses & Reference \\
\hline 1 & Fruit & Paste & Alexiteric & $(28)$ \\
\hline 2 & Fruit & Paste & Inflammations & $(28)$ \\
\hline 3 & Fruit & Paste & Scorpion- sting & $(25)$ \\
\hline 4 & Leaves & Paste & Applied to tuberculous glands & $(28)$ \\
\hline 5 & Leaves & Juice & Gargle & $(28)$ \\
\hline 6 & Fruit & Oil & Tinea corporis & $(29)$ \\
\hline 7 & Leaves & As such & To kill bugs & $(29)$ \\
\hline 8 & Ripe fruit & Oil & Scabies & $(29)$ \\
\hline 9 & Root & Paste & Sedative & $(29)$ \\
\hline 10 & Leaves & Paste & Antidote to venomous stings & $(30)$ \\
\hline 11 & Leaves & Paste & Epilepsy & $(23)$ \\
\hline 12 & Leaves & Eaten as such & Scabies & $(23)$ \\
\hline 13 & Root & Extract & Antifertility & $(22)$ \\
\hline 14 & Root & Boiled with milk & Tonic & $(26)$ \\
\hline 15 & Root & Paste & Cancer \& Rheumatism & $(27)$ \\
\hline 16 & Leaves & Eaten as such & Neck cancer & $(32)$ \\
\hline 17 & Leaves \& Roots & Eaten as such & Treatment of Tuberculosis \& sore throat & $(33)$ \\
\hline 18 & Fruit oil & Oil for local application & Eczema & $(34)$ \\
\hline 19 & Seeds \& fruits & Powder & $\begin{array}{l}\text { Asthama, Itching (Seeds) } \\
\text { \& Eczema(fruits) }\end{array}$ \\
\hline
\end{tabular}




\section{Phytoconstituents of $M$. annua}

Qualitative phyto-chemical screening of entire plant extracts of Martynia annua Linn demonstrates the existence of carbohydrates, glycosides, phenols, tannins, flavonoids and anthocyanins. GC-MS studied on aqueous and alcoholic extract of $M$. annua showed the existence of 28 compounds in which oleic acid present in the high amount. Other main organic compounds contain p-hydroxy benzoic acid, cyanidin-3-galactoside, pelargonidin-3-5diglucoside, gentisic acid, palmitic acid, linoleic acid, arachidic acid, stearic acid, apigenin, apigenin-7-oglucuronide. MEMA (methanolic extract of Martynia annua Linn) leaves exhibits the existence of higher amount of glycosides, alkaloids, terpenoid, tannins steroids, and saponins and moderate quantity of cardiac glycosides, anthroquinones and phenols While, it doesn't exhibits the existence of flavonoids and resins. The leaves mainly contain chlorogenic acid, sinapic acid, p-hydroxy benzoic acid and fatty acids such as palmitic acid and stearic acid. The flowers of the plant mainly contain cyanidin-3-galactoside and pelargonidin-3, 5-diglucoside while gentisic acids are there in fruits. The seeds show the existence of arachidic acid, cyclopropenoid, linoleic acid, malvalic acid, oleic acid, palmitic acid and stearic acid.(1) Table 3 provides a summary focusing on the phytoconstituents present in different parts of the plant.

Table 3: Phytoconstituents of Martynia annua Linn. plant

\begin{tabular}{|c|l|l|l|l|}
\hline S. No. & Plant part & Phyto-constituents & Type & Reference \\
\hline 1 & Fruits & Gentisic acid & Lipid & $(31)$ \\
\hline 2 & Leaves & Chlorogenic acid & Phenolic acids & $(36)$ \\
\hline 3 & Leaves & p-hydroxy benzoic acid & Phenolic acids & $(36)$ \\
\hline 4 & Seed & Arachidic acid & Lipid & $(37)$ \\
\hline 5 & Seed & HCN & Cyanogenic group & $(37)$ \\
\hline 6 & Seed & Linoleic acid & Lipid & $(37)$ \\
\hline 7 & Seed & Malvalic acid & - & $(37)$ \\
\hline 8 & Seed, leaves & Palmitic acid & Lipid & $(36)$ \\
\hline 9 & Seed, leaves & Stearic acid & Lipid & $(36)$ \\
\hline 10 & Seeds & Cyclopropenoid & - & $(37)$ \\
\hline 11 & Whole plant, Flowers & Pelargonidin-3,5-diglucoside & - & $(31)$ \\
\hline 12 & Whole plant, Flowers & Cyanidin-3-galactoside & - & $(31)$ \\
\hline 13 & Whole plant, Seed & Oleic acid & Lipid & $(37)$ \\
\hline 14 & Whole plant, Seed & Apigenin, Apigenin-7-O-beta- D- glucuronide & Flavonoids & $(38)$ \\
\hline
\end{tabular}

\section{Pharmacological Activities}

The plant has Analgesic and Antipyretic, Anthelmintic, Antibacterial, Anti-convulsant Antinociceptive and Central Nervous System (CNS) depressant, Antifertility, Antioxidant, Wound Healing, Antidiabetic, Gastroprotective, Antifungal and Cytotoxic Activity. The use of Martynia annua Linn as medicine is fairly large. A detailed view of the Pharmacological potentials of the plant is given in Table 4.

Table 4 : Pharmacological Activities of Martynia annua Linn.

\begin{tabular}{|l|l|l|l|l|}
\hline S.N. & $\begin{array}{l}\text { Type } \\
\text { activity }\end{array}$ & $\begin{array}{l}\text { Plant } \\
\text { Part }\end{array}$ & Research Activity \\
\hline 1 & $\begin{array}{l}\text { Analgesic } \\
\text { and } \\
\text { Antipyretic } \\
\text { Activity }\end{array}$ & Fruits & $\begin{array}{l}\text { The analgesic activity was studied by petroleum ether, chloroform, ethanol and } \\
\text { aqueous extracts of Martynia annua Linn. fruits on Swiss albino mice using hot } \\
\text { plate and tail flick methods and for antipyretic effect against brewers-yeast- } \\
\text { influenced hyperpyrexia in adult Wister rats. The all extract show significant } \\
\text { analgesic and antipyretic activity at 20 mg/kg. It was also observed that the } \\
\text { petroleum ether and chloroform extracts exhibits greater analgesic and } \\
\text { antipyretic activities as compared to ethanol and aqueous fruit extract of the } \\
\text { plant (Kar } \text { et al, 2007). }\end{array}$ \\
\hline 2 & $\begin{array}{l}\text { Anthelmintic } \\
\text { activity }\end{array}$ & Roots & $\begin{array}{l}\text { The antihelmintic activity against earthworms Pheritima posthuma was } \\
\text { investigated by petroleum ether extract of Martynia annua Linn. roots showed } \\
\text { effective result compared with the reference drug albendazole (Nirmal et al, } \\
\text { 2007). }\end{array}$ \\
\hline 3 & $\begin{array}{l}\text { Antibacterial } \\
\text { activity }\end{array}$ & Leaves & $\begin{array}{l}\text { The chloroform, ethyl acetate and methanol extract of Martynia annua L. leaves } \\
\text { were studied on gram positive and gram negative bacteria for antibacterial } \\
\text { activity. All the solvent extracts show antibacterial action respective to different } \\
\text { bacteria. Chloroform extract showed higher antibacterial activity against Proteus } \\
\text { vulgaris, Bacillus subtilis and B. thuringensis. Ethyl acetate extract was } \\
\text { potentially effective against Salmonella paratyphi A, Salmonella paratyphi B, } \\
\text { Proteus mirabilis, P. vulgaris and Klebsiella pneumonia, while the methnol } \\
\text { extract, shows greater antibacterial potential towards Proteus vulgaris, B. } \\
\text { subtilis, S. paratyphi B and Pseudomonas aeruginosa. The antibacterial activity } \\
\text { was carried out by Disc Diffusion method. (Sermakkani and Thangapandian, } \\
\text { 2010). }\end{array}$ \\
\hline
\end{tabular}




\begin{tabular}{|c|c|c|c|c|}
\hline S.N. & Type of activity & $\begin{array}{l}\text { Plant } \\
\text { Part }\end{array}$ & Research Activity & Ref. \\
\hline 4 & $\begin{array}{l}\text { Anti-convulsant } \\
\text { activity }\end{array}$ & Leaves & $\begin{array}{l}\text { The anticonvulsant activity was tested by methanol extract of Martynia } \\
\text { annua } \mathrm{L} \text { (MEMA) leaves at doses of } 200 \mathrm{mg} / \mathrm{kg} \text { and } 400 \mathrm{mg} / \mathrm{kg} \text {. The doses } \\
\text { were significantly reduced the duration of tonic hind leg extension and } \\
\text { protect the animals from seizures. The methanol extract of } M \text {. annua } 200 \\
\mathrm{mg} \text { per } \mathrm{kg} \text { and } 400 \mathrm{mg} \text { per } \mathrm{kg} \text { have revealed } 66.31 \% \text { and } 82.73 \% \\
\text { protection respectively against to maxima electroshock (MES) induced } \\
\text { seizures. For these comparisons, the standard drug phenytoin }(100 \%) \text { was } \\
\text { taken. While form the comparison with the standard drug diazepam }(100 \%) \\
\text { the MEMA } 200 \mathrm{mg} / \mathrm{kg} \text { and } 400 \mathrm{mg} / \mathrm{kg} \text { have also shown } 70.33 \% \text { and } \\
82.88 \% \text { protection of convulsion and } 83.33 \% \text { and } 100 \% \text { protection of } \\
\text { mortality respectively against pentylenetetrazol (PTZ) which induced } \\
\text { epilepsy. However, the anticonvulsant activity of MEMA was due to the } \\
\text { potentiation of neurotransmitter in brain (Babu et al., 2010). }\end{array}$ & (2) \\
\hline 5 & $\begin{array}{l}\text { Antinociceptive } \\
\text { activity and } \\
\text { Central Nervous } \\
\text { System (CNS) } \\
\text { depressant } \\
\text { activity }\end{array}$ & Roots & $\begin{array}{l}\text { For antinociceptive and CNS depressant activity petroleum ether, ethyl } \\
\text { acetate and methanol extracts of Martynia annua L. root were studied. } \\
\text { Amongst all extracts petroleum ether extract showed significant increase at } \\
\text { the dose of in reaction time by doing hot plate method and also showed } \\
\text { more inhibitory effect on standard drug pentazocine and paracetamol and } \\
\text { writhing induced by acetic acid against all extracts. Apart from this the } \\
\text { petroleum ether extract at } 50 \mathrm{mg} / \mathrm{kg} \text { dose also showed significant decrease } \\
\text { in the locomotor activity when they were compared with standard drug } \\
\text { diazepam. At the dose of } 30 \mathrm{mg} / \mathrm{kg} \text {, it potentiates pentobarbitone sodium } \\
\text { induced sleeping time up to } 215.34 \% \text { (Bhalke and Jadav, 2009). }\end{array}$ & $(34)$ \\
\hline 6 & $\begin{array}{l}\text { Antifertility } \\
\text { activity }\end{array}$ & Roots & $\begin{array}{l}\text { The antifertility effect on male rates by } 50 \% \text { ethanol extract of Martynia } \\
\text { annua L root at dose of } 50 \mathrm{mg} / \mathrm{kg}, 100 \mathrm{mg} / \mathrm{kg} \text { and } 200 \mathrm{mg} / \mathrm{kg} \text { body weight } \\
\text { were studied. The result revealed significant decreases in the weights of } \\
\text { testes, epididymitis, seminal vesicle and ventral prostate on male rats. } \\
\text { Moreover, the antifertility effect was found to be dose dependent without } \\
\text { changing general body metabolism (Mali et al., 2002). }\end{array}$ & $(22)$ \\
\hline \multirow[t]{3}{*}{7} & \multirow[t]{3}{*}{$\begin{array}{l}\text { Antioxidant } \\
\text { activity }\end{array}$} & Leaves & $\begin{array}{l}\text { The antioxidant activity of methanol and aqueous extract of Martynia } \\
\text { annua L. leaves were studied by in vitro methods, namely, reducing power } \\
\text { assay, DPPH radical-scavenging activity, nitric oxide scavenging activity, } \\
\mathrm{H}_{2} \mathrm{O}_{2} \text { radical scavenging activity, superoxide radical scavenging assay, } \\
\text { hydroxyl radical-scavenging activity, and total antioxidant capacity. The } \\
\text { higher antioxidant activity was found in methanolic extract compared to } \\
\text { aqueous extract (Nagda et al., 2009). }\end{array}$ & $(35)$ \\
\hline & & Fruit oil & $\begin{array}{l}\text { Rameshroo et al. reported in vitro antioxidant activity of } M \text {. annua from its } \\
\text { fruit oil. Superoxide radical and } \mathrm{DPPH} \text { radical methods were used for } \\
\text { assessing antioxidant effect where } \mathrm{IC}_{50} \text { being } 87.56 \mu \mathrm{g} / \mathrm{ml} \text { and } 106.80 \mu \mathrm{g} / \\
\mathrm{ml} \text { correspondingly. Fruit oil exhebits } 87.25 \pm 1.13 \mathrm{mg} \text { per } 100 \text { grams of } \\
\text { total polyphenol substance. As per the study report it is a prospective } \\
\text { source of natural antioxidants. }\end{array}$ & $(36)$ \\
\hline & & $\begin{array}{l}\text { Fruit } \\
\text { extracts }\end{array}$ & $\begin{array}{l}\text { The fruit extracts shows antioxidant potential which indicated that it can } \\
\text { help to inhance immune system. Antioxident activities deliberated by } \\
\text { various methods like DPPH free radical scavaning, ferric reducing power } \\
\text { and oxidative stress mechanism by lipid peroxidative assays. The ethanolic } \\
\text { fraction revealed maximum extent but in water these activities were also } \\
\text { significant. The phenolic compounds and flavonoids are responsible of } \\
\text { antioxidant activities. }\end{array}$ & $(37)$ \\
\hline 8 & $\begin{array}{ll}\text { Study } & \text { On } \\
\text { Antioxidant } & \\
\text { Potential } & \end{array}$ & $\begin{array}{l}\text { Leaf, } \\
\text { stem \& } \\
\text { endocarp } \\
\text { with seed }\end{array}$ & $\begin{array}{l}\text { In this study ascorbic acid, flavonoid, tannin and phenol content of different } \\
\text { parts of } M \text {. annua using spectrophotometric methods were studied. The } \\
\text { result of this study revealed that the leaf and stem of } M \text {. annua have } \\
\text { significant amount of flavonoids, phenols, tannins and ascorbic acids } \\
\text { compared to endocarp with seed. Study revealed that } M \text {. annua is a } \\
\text { potential source of natural antioxidants. }\end{array}$ & $(38)$ \\
\hline 9 & $\begin{array}{l}\text { Wound Healing } \\
\text { activity }\end{array}$ & Leaves & $\begin{array}{l}\text { The wound healing effect was studied by methanol fraction of ethanolic } \\
\text { extract of Martynia annua L. leaves which shows significant by stimulating } \\
\text { of wound contraction as well as epithelialization. Moreover the } \\
\text { phytochemical studies was tested and evaluated that the methanol fraction } \\
\text { mainly contains flavonoid, luteolin which were responsible for } \\
\text { enhancement of wound healing process due to the free radical scavenging } \\
\text { mechanism (Lodhi and Singhai, 2011; Dhingra et al., 2013). }\end{array}$ & $(27)$ \\
\hline
\end{tabular}




\begin{tabular}{|c|c|c|c|c|}
\hline S.N. & $\begin{array}{ll}\text { Type } & \text { of } \\
\text { activity } & \end{array}$ & $\begin{array}{l}\text { Plant } \\
\text { Part }\end{array}$ & Research Activity & Ref. \\
\hline & $\begin{array}{l}\text { Comparative } \\
\text { Antioxidant } \\
\text { Potential of Its } \\
\text { Stem and } \\
\text { Leaves }\end{array}$ & $\begin{array}{l}\text { Stem } \\
\text { and } \\
\text { leaves }\end{array}$ & $\begin{array}{l}\text { The comparative antioxidant potential and radical scavenging activities were } \\
\text { studied using different antioxidant assays such as ferric reducing antioxidant } \\
\text { power (FRAP), 2,2'-diphenyl-1-picrylhydrazil (DPPH) scavenging, total } \\
\text { phenolic contents (TPC) and total antioxidant activity by phosphomolybdenum } \\
\text { complex method. The study results revealed that n-butanol soluble fraction of } \\
\text { stem showed highest \% scavenging of DPPH }(83.62 \pm 0.38 \% \text { at concentration } \\
\text { of } 250 \mu \mathrm{g} / \mathrm{mL}) \text { as compared to other studied fractions. The ethyl acetate } \\
\text { soluble fraction of leaves also displayed good activity }(82.88 \pm 0.34 \%) \text { nearly } \\
\text { equal to it. }\end{array}$ & $(39)$ \\
\hline & $\begin{array}{l}\text { Anti-diabetic } \\
\text { Activity }\end{array}$ & Flower & $\begin{array}{l}\text { The antidiabetic activity of methanol extracts of Martynia annua L (MEMA) } \\
\text { flower studied by Saiyad and Gohil (2013) in streptozotocin (STZ) and } \\
\text { Streptozotocin- Nicotinamide (STZ-NIC) which induced diabetes in Wistar } \\
\text { rats. MEMA showed tremendous reductions in blood glucose, triglyceride and } \\
\text { glycosylated hemoglobin levels and showed the increased HDL levels in } \\
\text { diabetic rats (after } 21 \text { days). A result discovered that the MEMA exhibited } \\
\text { good antidiabetic activity in STZ and STZ-NIC which induced diabetic rats } \\
\text { (Kenwat et al.,2013). }\end{array}$ & $(48)$ \\
\hline & $\begin{array}{l}\text { Gastro- } \\
\text { protective } \\
\text { Activity }\end{array}$ & Leaves & $\begin{array}{l}\text { Jain and Bhandarkar reported gastroprotective activity of MEMA leaves in rats } \\
\text { with } 200 \mathrm{mg} / \mathrm{kg} \text { and } 300 \mathrm{mg} / \mathrm{kg} \text { body weight on ethanol-induced gastric ulcer. } \\
\text { Results were observed by calculating ulcer index based on lesion index and } \mathrm{pH} \\
\text { which showed significant inhibition on the ulcer lesion index in rats hence } \\
\text { effect of ethanol extract with } 300 \mathrm{mg} / \mathrm{kg} \text { dose significantly }(\mathrm{p}<0.05) \text { change } \\
\text { the gastric volume, ulcer index, and } \mathrm{pH} \text {. }\end{array}$ & $(49)$ \\
\hline & $\begin{array}{l}\text { Antifungal } \\
\text { Activity }\end{array}$ & $\begin{array}{l}\text { Whole } \\
\text { plant }\end{array}$ & $\begin{array}{l}\text { The antifungal activity of Martynia annua } \mathrm{L} \text { along with thirteen coastal sand } \\
\text { dune plants (CSDPs) belonging to nine families were studied from Arnala and } \\
\text { Kalamb beach. The results obtained and suggest that, } 90 \% \text { colonization were } \\
\text { found } C \text {. rotundus, E. zeylanica var. zeylanica, I. pes-caprae (Arnala beach), } \\
\text { L. procumbens (Kalamb beach), Martynia annua, P. punctatum and } S \text {. } \\
\text { orientale etc. (Kumar et al, 2012). }\end{array}$ & $(50)$ \\
\hline & $\begin{array}{l}\text { Cytotoxic } \\
\text { Activity }\end{array}$ & Leaves & $\begin{array}{l}\text { Cytotoxic activity of alcoholic and acetone extracts of } M \text {. annua was studied } \\
\text { by J.Vinnarasi et al (2014) in terms of brine shrimp lethality bioassay. The } \\
\text { alcoholic and acetone extracts of } M \text {. annua was observed to be mainly } \\
\text { effective at which half mortality of brine shrimp nauplii occurred were found } \\
\text { to be } 239.48 \text { and } 328.21 \mathrm{ppm} \text { respectively. The results of the study revealed the } \\
\text { cytotoxic Potential of M.annua.( J.Vinnarasi et al, 2014) }\end{array}$ & $(51)$ \\
\hline
\end{tabular}

\section{Conclusion}

Though Martynia annua Linn. is an invasive obnoxious weed, the literature survey reveals the therapeutic efficiency of the plant. The phytochemicals isolated from this medicinal plant has been effectively using in many health problems since a long time. The present review work provides a wide area of interest for planning and conducting research on this wonderful plant for the development of novel drug for the future.

\section{References}

1. http://www.backyardnature.net/q/martynia.htm Sierra Gorda Biosphere Reserve, QUERÉTARO, MÉXICO September 14, 2007 [Internet]. [cited 2018 Apr 15]. Available from: http:// www.backyardnature.net/q/martynia.htm

2. Babu HB et al. Studies on phytochemical and anticonvulsant property of Martynia annua Linn. International Journal of Phytopharmacology 2010; 1 (2): 82-86.

3. Kumar Shankul et al, Pharmacognostical, phytochemical and pharmacological review on Ipomoea carnea,Novus International Journal of Pharmaceutical Technology 2012, 1(4):9-18.

4. Kumar $\mathrm{S}$ et al. systemic review: pharmacognosy, phytochemistry and pharmacology of martynia. Int J
Res Med. 2012; 1(1):34-39.

5. Charak Samhita, with Charaka Chandrika Hindi commentary, by Dr. Brahmanand Tripathi and Dr. Ganga Sahay Pandey, Chikista Sthana Chapter 1/1, Verse No. 64 Chaukhamba Surbharti Prakashan, 2007.p.21. In.

6. Charak Samhita, with Charaka Chandrika Hindi commentary, by Dr. Brahmanand Tripathi and Dr. Ganga Sahay Pandey, Chikista Sthana Chapter 18, Verse No. 41-42 Chaukhamba Surbharti Prakashan, 2007.p.647. In.

7. Charak Samhita, with Charaka Chandrika Hindi commentary, by Dr. Brahmanand Tripathi and Dr. Ganga Sahay Pandey, Chikista Sthana Chapter 10, Verse No. 38 Chaukhamba Surbharti Prakashan, 2007.p.414. In.

8. Charak Samhita, with Charaka Chandrika Hindi commentary, by Dr. Brahmanand Tripathi and Dr. Ganga Sahay Pandey, Chikista Sthana Chapter 30, Verse No. 50-51 Chaukhamba Surbharti Prakashan, 2007.p.1019. In.

9. Yadavji Trikamji, Narayan Ram, editors, Sushruta Samhita of Sushruta, Chikitsa sthan, chapter 37, verse 13,20 , 5th edn (reprint), Varanasi: Chaukhamba orientalia; 1992;. In. 
10. Sharma PV (2008), Editor of Dhanwantari Nighantu, Chaukhambha orientalia, Varanasi. pg no. 125 . In.

11. Sharma P.V, Kaidev Nighantu, 1st Edition 1979, Chowkhamba Orienta, Varanasi, Delhi; p.- 133. In.

12. Pandey.G.S, Bhavprakash Nighantu, 4thEdition1969, Chowkhamba Snaskrit Snasthan, Varanasi,p -440. In.

13. Narahari P, Raj Nighantu, Edited by Indradev Tripathi , 1st Edition, Krishna Das Academy, Varanasi, p.- 51. In.

14. Vaidya Bapala G1, Nighantu Adarsha, 1st Edition 1968, Chowkhamba Vidyabhavan, Varanasi, Uttarardha, p -25. In.

15. Chopra RN et al. Glossary of Indian Medicinal plants, National Institute of Science Communication, New Delhi 1996; 181.

16. Kirtikar K R; Basu B D, Indian Medicinal Plants, Vol.III, International Book Distributors and Publisher, Dehradun, 1999, 1994:1730.

17. Oudhia P. Medicinal weeds in groundnut fields of Chhattisgarh (India). Int.Arachis News let. 1999; 19: 62- 64.

18. Trease GE, Evans WC. Trease and Evans Pharmacognosy: A Physicians guide to Herbal Medicine 13th Edition, Bailliere Tindall. London, 1989.

19. Katare V et al. Phytochemical and Pharmacognostical studies of Martynia annua. IRJP. 2012; 3(6): 104-08.

20. The Ayurvedic Pharmacopoeia of India, Part I, volume III, page no.120-22.

21. Subhangkar N. Shankul Kumar et al. systemic review: pharmacognosy, phytochemistry and pharmacology of Martynia annua Int J Res Med. (2012),1(1),34-39. 2012;5.

22. Anonymous. The Ayurvedic Pharmacopoeia of India. Part I, Vol. III, Ministry of Health \& Family Welfare, Government of India, New Delhi, 77- 78. In.

23. Anonymous. The Wealth of India. Publication and information Directorate, CSIR, New Delhi, 1985, 307.

24. Bansode S, Nirmal S, Jadhav R. Pharmacognostic, phytochemical and pharmacological study of Martynia annua Leaves" (Family: Martyniaceae). $: 4$.

25. http://www.efloraofgandhinagar.in/herb/martyniaannua 15/4/2018.

26. "Study on Utilization Pattern of Plants in EthnoMedicinal Uses Prevalent in Tribal Pockets of Satpura Plateau in Madhya Pradesh" by Madhya Pradesh State Biodiversity Board, Bhopal (M.P.) Traditional healers (Village - Marhapatha, Block Bargi, Dist. - Jabalpur (Madhyapradesh).

27. Mhaskar KS, Blatter E, Caius JF. Indian Medicinal Plants. Vol. II, Sri Satguru Publications; Delhi, 2000, 556-559.

28. Singh NP, Panda H. Meditional herbs with their formulation. Daya Publishing House, New Delhi, 2005, 671.

29. Watt G. Dictionary of the economic products of
India. Vol. V, Cosmo Publications; New Delhi,1972.

30. Mali PC, Ansari AS, Chaturedi M. Antifertility effect of chronically administered $M$. annua root extract on male rats. Journal of Ethnopharmacology 2002; 82(2-3): 61-67.

31. Pandey G, Sharma M. Govind Pandey, S Madhuri Some medicinal plants as natural anticancer agents, pharmacognosy review Year : 2009 Vol: 3 Issue :6 P- 259-263. Pharmacogn Rev. 2014 Dec 31;3:25963.

32. Gurrapu S. Gurrapu et al. Medicinal Plants Used By Traditional Medicine Practitioners In The Management Of HIV/AIDS-Related Diseases In Tribal Areas Of Adilabad District, Telangana Region. Am J Sci Med Res [Internet]. 2017 Aug 10 [cited 2018 Apr 15];2(1):239-45. Available from: http://globalsciencepg.org/21.01\%20swapna\%20239 $-245 . p d f$

33. Chinna Eswaraiah M et al. an overview on Martynia annua L. International Journal of Pharmaceutical Research \& Development 2013; Vol 5(02): April2013 (113 - 118) [Internet]. [cited 2018 Apr 15]. Available from: https://www.ijprd.com/AN\% 20OVERVIEW\%20ON\%20MARTYNIA\% 20ANNUA\%20L.pdf

34. Martynia annua Linn: A traditional Drug for Asthama, Itch and Eczema, Short Research communication, 2 (3) 1981 (P. 427 )Ab.pdf [Internet]. [cited 2018 Apr 15]. Available from: http://www.ccras.nic.in/sites/default/files/viewpdf/ jdras/Archieves/Volume_02_No._3_Spet_1981/2\%

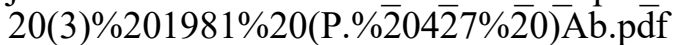

35. Lodhi S, Singhai A K. Preliminary pharmacological evaluation of Martynia annua Linn leaves for wound healing. Asian Pacific Journal of Tropical Biomedicine 2011; 1(6): 421-427.

36. Hosamani KM, Sattigeri RM, Patil KB. Studies on chemical compounds of Martynia annua syn. M. diandra seed oil. Journal of Medicinal and Aromatic Plant Sciences 2002; 24(1): 12.

37. Rastogi RP, Melhotra BN. Compendium of Indian Medicinal Plants. Vol. II, CDRI, Lucknow, 1993, 446.

38. Kar D M et al. Analgesic and antipyretic activity of fruits of Martynia annua Linn. Hamdard Med. 2004; 47: 32 .

39. Nirmal SA, Nikalye AG, Jadav RS, Tambe VD. Anthelmintic activity of Martynia annua roots. Indian Drugs. 2007; 44(10): 772-773.

40. Sermakkani M, Thangapandian V. Antibacterial and phytochemical analysis of Martynia annua L. Plant Archives. 2010; 10(1): 223-225.

41. Bhalke RD, Jadhav RS. Antinociceptive activity and CNS depressant activity of Martynia annua L. root.

42. Nagda D, Saluja A, Nagda C. Antioxidant activities of methanolic and aqueous extract from leaves of Martynia annua Linn. Journal of pharmacognosy. 2009; 1: 288-297.

43. Kenwat $\mathrm{R}$ et al. Preliminary phytochemical screening and in vitro antioxidant efficacy of fruit oil of Martynia annua. UK J Pharm Biosci 2014;2:16-22. 
44. Arshad Z, Saied S, Naz S. Antioxidant Activities and Phytochemical Screening of Martynia annua Fruit Extract. Biosci Biotechnol Res Asia [Internet]. 2017 Dec 25 [cited 2018 Apr 15];14(4):1363-9. Available from: http://www.biotech-asia.org/ vol14no4/antioxident-activities-and-phytochemicalscreening-of-martynia-annua-fruit-extract/

45. Flora G, et al., Study on Antioxidant Potential Of Different Parts Of M. annua Linn. IJDR, Vol. 3, Issue, 9, pp.051-054, September, 2013.

46. Aziz-Ur-Rehman et al., Martynia annua: Comparative Antioxidant Potential of Its Stem and Leaves, Asian Journal of Chemistry; Vol. 24, No. 8 (2012), 3335-3338.

47. Saiyad Moinali F, Gohil Kashmira J. To investigate anti-diabetic potential of Martynia annua Linn. flower extracts in wistar rats. WJPR.2013; 2(2): 486 -499 .

48. Jain Suchit, Bhandarkar Sharad, Gastroprotective activity of leaves on ethanol induced ulcer in rats, Asian Journal of Pharmacy and Pharmacology 2016; 2(1):19-22.

49. Vishal R. Kamble, Bazegah K. Sayed and Nazia Qureshi. Screening of CSDPs for AM Fungal Association from Arnala and Kalamb Beach Maharashtra, IOSR Journal of Pharmacy and Biological Sciences 2012; 2(4):44-47.

50. Vinnarasi J, Raj AAA, Rose GL. Phytochemical Screening and Cytotoxic Activity of Martynia annua L. Leaves Extracts. 2014;4. 